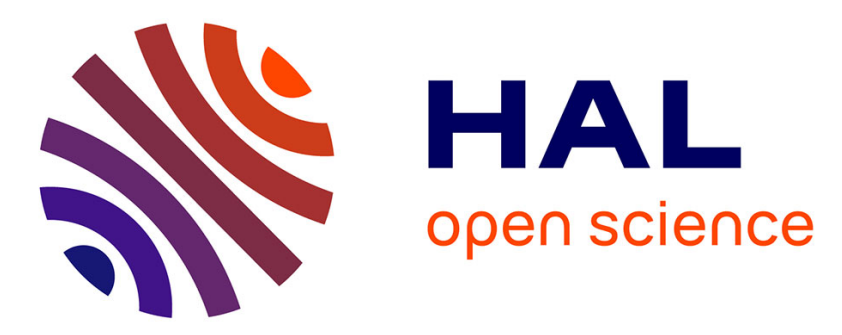

\title{
A rare cause of acute coronary syndrome in a handyman
} Marie Viala, Benoit Lattuca, Thomas Vacter, François Roubille

\section{To cite this version:}

Marie Viala, Benoit Lattuca, Thomas Vacter, François Roubille. A rare cause of acute coronary syndrome in a handyman. International Journal of Cardiology, 2016, 203, pp.594 - 595. 10.1016/j.ijcard.2015.10.230 . hal-01802389

\section{HAL Id: hal-01802389 \\ https://hal.umontpellier.fr/hal-01802389}

Submitted on 10 Dec 2019

HAL is a multi-disciplinary open access archive for the deposit and dissemination of scientific research documents, whether they are published or not. The documents may come from teaching and research institutions in France or abroad, or from public or private research centers.
L'archive ouverte pluridisciplinaire HAL, est destinée au dépôt et à la diffusion de documents scientifiques de niveau recherche, publiés ou non, émanant des établissements d'enseignement et de recherche français ou étrangers, des laboratoires publics ou privés. 


\title{
A rare cause of acute coronary syndrome in a handyman
}

\author{
Marie Viala ${ }^{\mathrm{a}}$, Benoit Lattuca ${ }^{\mathrm{a}}$, Thomas Vacter ${ }^{\mathrm{a}}$, François Roubille ${ }^{\mathrm{a}, \mathrm{b}, *}$ \\ a Cardiology Department, University Hospital Arnaud de Villeneuve, University of Montpellier, 371, avenue du Doyen Gaston Giraud, 34295 Montpellier cedex 5, France \\ b PhyMedExp, University of Montpellier, INSERM U1046, CNRS UMR 9214, 34295 Montpellier cedex 5, France
}

Keywords:

Acute coronary syndrome

Optical coherence tomography

Vibration

Intramural hematoma

Spontaneous coronary dissection is a very rare cause of acute coronary syndrome (ACS), probably caused by a rupture of vasa vasorum, and frequently associated with non-atherosclerotic arteries.

The typical clinical presentation is a young woman without medical history who presents an ACS. It is most often a dissection of the mild left anterior descending artery. Many pathological conditions are associated such as hormonal factors, fibromuscular dysplasia, connective tissue diseases and heavy isometric exercise [1].

Usually coronary angiogram achieves the diagnosis with evidence of an intimal flap generating 2 lumens (true and false lumens). However, coronary angiogram appears sometimes normal but systematic coronary imaging and particularly optical coherence tomography (OCT) is able to achieve the diagnosis. It provides an accurate visualization of the intimomedial membrane [2] and evidence abnormal arterial wall with dissection coronary or intramural coronary hematoma.

We report a case of a 41 year old Caucasian man presented with new onset prolonged angina pectoris.

He had no coronary risk factor and no previous history of heart disease. His family history was unremarkable.

He was admitted in the cardiology intensive care unit for an acute typical angina pectoris, which occurred after he drilled a metallic plate. He reported this was responsible for a lot of vibrations. The pain lasted $2 \mathrm{~h}$ and stopped spontaneously.

On admission, he had no more chest pain. His blood pressure was $130 / 65 \mathrm{~mm} \mathrm{Hg}$ and his heart rate was 58 beats per minute with a normal cardiopulmonary auscultation. An electrocardiogram (ECG) on

\footnotetext{
* Corresponding author at: Cardiology Department, University Hospital of Montpellier, Montpellier, France.

E-mail address: francois.roubille@gmail.com (F. Roubille).
}

admission showed only an early repolarization without ST segment or T wave disorders.

A transthoracic echocardiogram showed inferior hypokinesia with a $55 \%$ left ventricular ejection fraction.

Highly-sensitive troponin was significantly up to $790 \mathrm{ng} / \mathrm{L} 3 \mathrm{~h}$ later onset of pain (normal value $<14 \mathrm{ng} / \mathrm{L}$ ). There was no sign of inflammation and C-reactive protein level was $1.1 \mathrm{mg} / \mathrm{L}$ (normal value $<3 \mathrm{mg} / \mathrm{L}$ ).

The patient was given a treatment with $250 \mathrm{mg}$ intravenous aspegic, $180 \mathrm{mg}$ ticagrelor and $35 \mathrm{mg}$ intravenous enoxaparin.

A coronary angiogram was performed and revealed a coronary dissection of the distal right coronary artery with no additional significant lesion. (Fig. 1).

No percutaneous coronary intervention $(\mathrm{PCI})$ was proposed given that the distal location and the reduced extension of the coronary dissection.

The diagnosis of myocardial infarction was confirmed by cardiac Magnetic Resonance Imaging, showing hyper enhancement in the inferior territory.

Coronary tomography scan was also performed but appears no contributing to confirm coronary dissection of the distal right coronary artery because of a lower definition due to a smaller diameter of the artery.

Our patient remained stable, with no recurrent chest pain. The coronary dissection was distal and not responsible of a significant residual stenosis. Moreover, the coronary flow was normal. In this case, PCI could be complicated: propagation of the hematoma and compromised coronary flow, stent under sizing, stent malapposition after resorption of the hematoma.

We proposed a conservative management. The medical treatment comported rest, betablocker, dual antiplatelet therapy and statin. A coronary angiogram was scheduled after one month of medical treatment. Exploration of body's main arteries was performed during the hospitalization and revealed no artery pathology.

The evolution was good without hemodynamic or rhythmic complications.

The coronary angiogram control was performed one month later, and was normal.

However, a systematic OCT showed a long intramural coronary hematoma of $13 \mathrm{~mm}$-length consistent with the initial angiographic lesion in the distal right coronary artery. Furthermore, the OCT revealed another intramural coronary hematoma on the mild right coronary artery, which was not suspected on the coronary angiogram (Fig. 2).

To our knowledge, this is the first published case of a dissection coronary artery related to vibrations. 


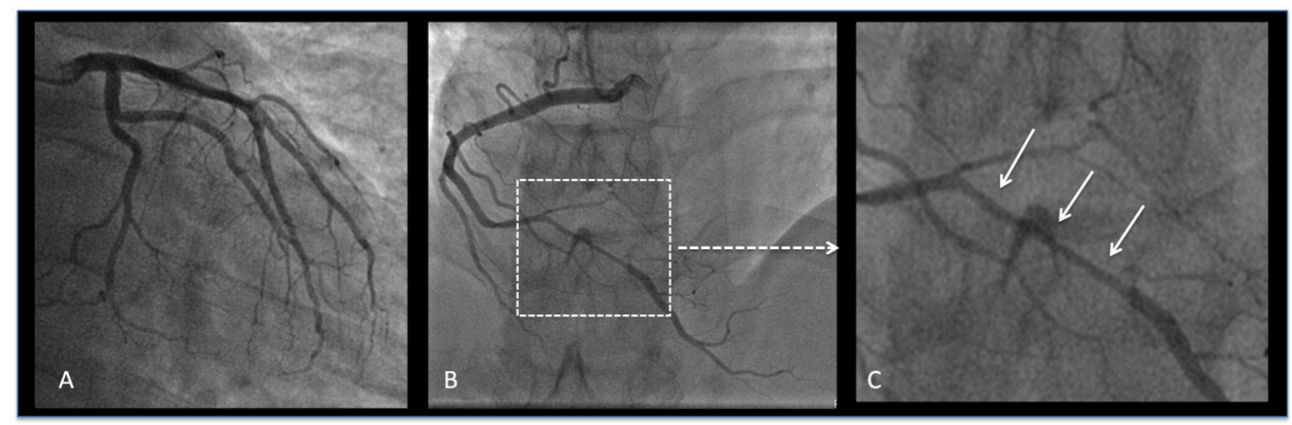

Fig. 1. Initial coronary angiogram, A: left coronary arteries, B: right coronary artery, C: zoom in on dissection (arrows).

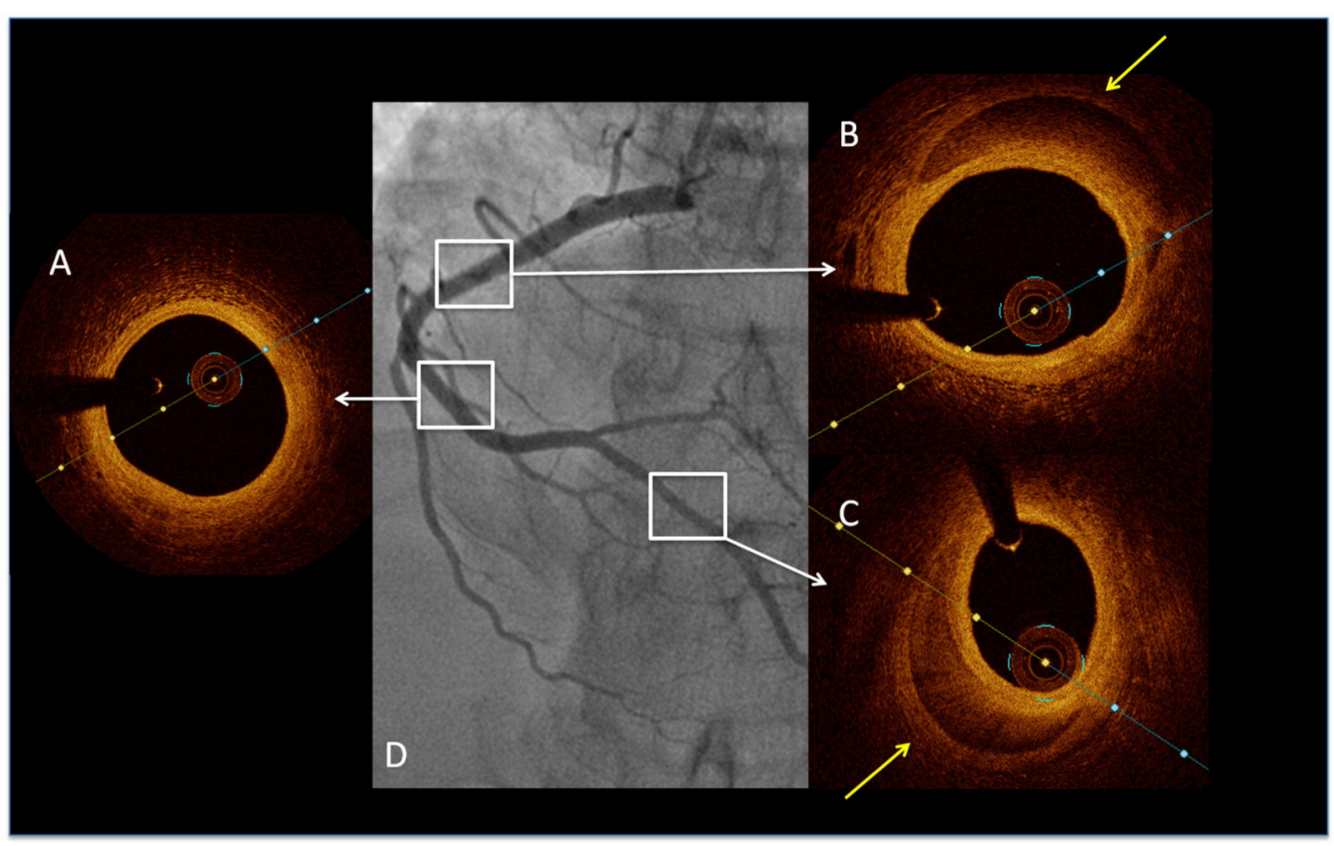

Fig. 2. After 1 month of follow-up, angiographic and OCT control (A), (B) mild and (C) distal right coronary artery, arrows show subadventitial hematoma, (D) angiography.

The absence of intimal flap or angiographic significant lesion makes diagnosis of intramural coronary hematoma difficult. Role of coronary imaging is crucial to define therapeutic management especially in context of ACS even if treatment of an ACS due to a spontaneous coronary dissection remains controversial without any dedicated guidelines. However, medical treatment and conservative management is proposed when possible, and spontaneous healing generally occurs [3].

\section{Conflict of interest}

The authors report no relationships that could be construed as a conflict of interest.

\section{References}

[1] J. Saw, E. Aymong, T. Sedlak, et al., Spontaneous coronary artery dissection: association with predisposing arteriopathies and precipitating stressors and cardiovascular outcomes, Circ. Cardiovasc. Interv. 7 (2014) 645-655.

[2] F. Alfonso, T. Bastante, J. Cuesta, D. Rodríguez, A. Benedicto, F. Rivero, Spontaneous coronary artery dissection: novel insights on diagnosis and management, Cardiovasc. Diagn. Ther. 5 (2) (2015) 133-140, http://dx.doi.org/10.3978/j.issn.2223-3652.2015. 03.05 .

[3] M.S. Tweet, M.F. Eleid, P.J. Best, et al., Spontaneous coronary artery dissection: revascularization versus conservative therapy, Circ. Cardiovasc. Interv. 7 (2014) 777-786. 